\title{
Preverbs in Russian: situation or viewpoint aspect?
}

\section{Eric Corre}

\section{(2) OpenEdition \\ Journals}

Electronic version

URL: http://journals.openedition.org/rlv/2285

DOI: $10.4000 /$ rlv.2285

ISSN: 1958-9239

\section{Publisher}

Presses universitaires de Vincennes

\section{Printed version}

Date of publication: 1 January 2015

Number of pages: $97-122$

ISBN: 978-2-84292-417-1

ISSN: 0986-6124

\section{Electronic reference}

Eric Corre, «Preverbs in Russian: situation or viewpoint aspect? », Recherches linquistiques de Vincennes [Online], 43 | 2015, Online since 01 January 2017, connection on 24 April 2019. URL : http:// journals.openedition.org/rlv/2285; DOI : 10.4000/rlv.2285 


\title{
Eric CORRE
}

\section{Université Paris 3-Sorbonne Nouvelle}

PREVERBS IN RUSSIAN: SITUATION OR VIEWPOINT ASPECT?

\begin{abstract}
The present paper has two goals: to present the complex data of verbal prefixation of Russian, and to assess the validity of the Situation Aspect-Viewpoint Aspect (Smith 1991) distinction for preverbs, in particular the thesis that all preverbs are telicity-markers (Borer 2005). First, arguments are introduced to show that all prefixed verbs are automatically perfective (pf), all are subject to lexical restrictions. A preliminary conclusion is that all preverbs are telicity markers, contra Filip $(2005,2008)$ for whom the preverb is pre-functional (lexical). This raises the question of the exact nature of telicity. In the literature (Dowty 1979, Krifka 1998), telicity is tested by means of in x time frame adverbials. A more relaxed version of telicity is proposed, following Borer (2005) \& Lakorczyk (2010): it suffices for an event to be either non divisive or non homogeneous to be telic. The concept is akin to Paducheva \& Pentus' (2008) terminativity: the function of the preverb is to seal off the event. This accounts for the behavior of po-delimitative verbs. The data show that some assumptions are not correct: po-delim verbs are currently extending their functional scope in Russian and often act as pf partners to impf verbs, they do not necessarily indicate short duration, and are subject to lexical restrictions (Dickey 2006). Finally, the role of the preverb with respect to viewpoint aspect is assessed. The conclusion is that it is Situation Aspect that is grammaticized in Russian by means of the preverbs, and not viewpoint aspect, which is derived by means of correlations.
\end{abstract}

\section{KEYWORDS}

Russian, viewpoint aspect, situation aspect, telicity, perfectivity. 


\section{Introduction}

Many languages use adpositional morphemes, either verbal prefixes (henceforth, preverbs) or particles, as a means to extend the morphological possibilities, and consequently the lexical inventory, of verbs. Such morphemes traditionally add spatial and/or directional, temporal and/or aspectual, or simply idiosyncratic, information to a verb's root. In Russian, where the system of temporal marking is impoverished (reduced to one present-future tense and one past tense), preverbs are used to encode such distinctions. Each verb is either soveršennyj ("accomplished", translated as "perfective", henceforth pf) or nesoveršennyj ("unaccomplished", translated as "imperfective", henceforth impf). The vast majority of base verbs (or simplex stems) are impf, but there are exceptions. The addition of a preverb systematically derives a corresponding pf verb, as in (1):
a. Poka on e-l
buterbrod, za-zvoni-l
while 3SG eat.IMPF-PST.3SG sandwich, za-ring.PF-PST.3SG phone
'While he was eating the sandwich, the phone rang.'
b. On s'-e-l buterbrod $i$ lëg spat'.
3SG s'-eat.PF-PST.3SG sandwich and go.PF.PST.3SG to-bed
'He ate (finished eating) his sandwich and went to bed.'

telefon.

This example has an Acccomplishment VP: the (a) sentence, which describes a progressive event, requires the use of the impf bare verb, while the (b) sentence, which forces a perfective viewpoint, has the preverb s'-added to the impf root, and the verb becomes pf. This contrast raises the question of the role of the preverb: does it encode viewpoint aspect, i.e., the perfective viewpoint much like the simple past in English, or is it, rather, a telicizer which adds an inherent limit to the verb's denotation, or does it fulfil both functions?

Aktionsart, or situation aspect (henceforth, SA), concerns inner aspect, i.e., whether a given VP implies an inherent endpoint to the event. Viewpoint aspect (henceforth, VA), or outer aspect, concerns the relation between the event and a temporal interval: the perfective viewpoint includes both endpoints of the event within a closed temporal interval, while the imperfective viewpoint includes part of the event within an open interval. The data in (1) are incomplete; they suggest that the morphology - presence $v s$ absence of the preverb - affects both SA and VA. But the base verb, i.e. the morphologically impf verb in Russian, can in fact express perfective VA:

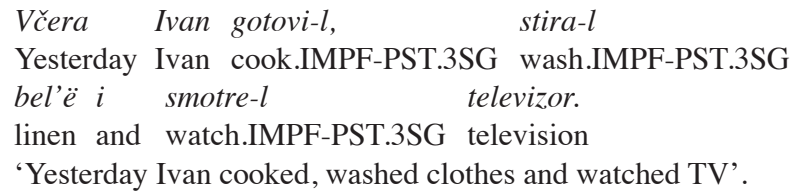


In (2), the event is presented perfectively, i.e., with both endpoints included in the assertion time: at Utterance Time (UT), Ivan has finished cooking, washing his clothes and watching TV. Yet statements like these do not require a preverb. Such data are problematic for proponents of preverbs as markers of VA.

This paper will defend the somewhat unorthodox view that viewpoint perfective aspect is not marked by the preverbs, that VA is neutral in Russian, and that it is SA that is grammaticized. VA is merely inferred through compositional restrictions or simply correlations. It is organized as follows: after discussing the classification into three types of preverbs found in the literature (section 2), we will show that it is possible to provide a unified account of the functional role of preverbs, that of marking telicity (section 3), but crucially, not telicity as generally discussed in the literature. Instead, the case of po-delimitative verbs, a special class of prefixed pf verbs which resist traditional telicity tests, will help us establish the notion of telicity as terminativity (section 4). Section 5 will take up the discussion of the exact role of the preverbs in marking SA or VA, and will conclude in favor of the former hypothesis.

\section{Three types of preverbs in Slavic}

The division of preverbs into aspectual types has a long history in Slavic linguistics. The overarching distinction has been that between the formal category of aspect ( $v i d$ ) and the lexical category of Aktionsart (sposoby dejstvija, or "modes of action"). It has been assumed that all the preverbs have semantic content, although this content may not be perceptible because of a semantic overlap with the meaning of the verb (Isačenko 1960). The loss of the tense system in Old Russian gave the preverbs new life, however, as they were called upon to ensure the aspectual-temporal marking no longer available on the verb. Slavic aspect is considered to be typologically exceptional (Comrie 1976, Tournadre 2004), since it relies so heavily on derivational morphology to encode grammatical distinctions, blurring the boundaries between SA and VA. A long-standing tradition distributes the preverbs over three main categories according to their aspect or Aktionsart function.

\subsection{Meaning-modifying, lexical or "specialized perfectives" (Janda 2007)}

There are twenty or so preverbs which constitute the privileged means whereby Russian derives new verbal lexemes. The principle is as follows: a simplex (in the vast majority of cases an impf, dynamic or not) verb, e.g. bit', 'beat, hit', combines with one or more of the twenty prefixes, deriving a new lexical unit which are automatically pf. 
(3) u-bit' (čeloveka), 'kill (a man)'; raz-bit' (stakan), 'break (a glass)';

po-bit' (sobaku), 'beat a dog'; pro-bit' (dorogu), 'open up (road)';

za-bit' (trevogu), 'raise (the alarm)'...

Then, as the system rests on aspectual pairing, an impf partner is now needed for these new verbs. This is achieved through the regular process of secondary imperfective (SI) suffixation by means of -a/-iva/-yva suffixes (depending on the stem):

$$
\begin{aligned}
& \text { u-bi-va-t'; raz-bi-vat'; po-bi-vat'; pro-bi-vat'; za-bi-vat'. } \\
& \text { u-STEM-2.IMPF-INF }{ }^{1}
\end{aligned}
$$

\subsection{Purely perfectivizing or empty preverbs, or "natural perfectives" (Janda 2007)}

At the other end of the spectrum is the "empty" preverb, discussed by Maslov (1948), Vinogradov (1972), Tixonov (1962), Avilova (1976), among others. These preverbs form an aspectual pair with the base verb without changing its meaning. For example, the base impf verb pisat', 'write', is paired with napisat', 'preverb-write', which is used whenever the notion pisat' is used in a perfective context.

pisat'/na-pisat', 'write'; čitat'/pro-čitat', 'read'; delat'/s-delat', 'do'; gotovit'/pri-gotovit', 'prepare'; stroit'/po-stroit', 'build'; slyšat'/u-slyšat', 'hear'; myt'/vy-myt', 'wash'; platit'/za-platit', 'pay'; portit'/is-portit', 'waste, damage'...

One overwhelming piece of evidence in favor of the purely functional role of the empty preverb is that these prefixed perfectives do not derive a secondary impf, although it would be morphologically possible to do so: *napisyvat', *sdelyvat', *postraivat', *zaplačivat', etc., do not exist.

The concept of aspectual pairing has generally been described in semantic terms: the most natural aspectual verbal pair is one in which the impf verb denotes the development phase of the dynamic event while the prefixed pf verb indicates attainment of the telos, deriving an accomplishment or an achievement. This process has had the effect of excluding stative verbs (which lack a telos), activity verbs (which are atelic), and degree achievement verbs (which lack an inherent final point). Yet, with few exceptions, all verbs in Russian have an aspectual correlate. This has led some authors, notably Filip (2006), to call into question the systematic telicity-marking role of the preverbs: states, activities and degree achievements being deprived of a telos in their denotation, the preverb cannot mark telicity. In section 4 , we will see

1. Secondary imperfective suffixation will be glossed as '2.IMPF', as in the example provided. 
that it is possible to give a unified account of pf prefixation if we relax the requirement that preverbs indicate the attainment of the lexical telos.

\section{3. "Superlexical preverbs", "procedurals" (Forsyth 1970) or "complex acts" (Janda 2007)}

The superlexical preverbs yield complex events. They take an activity verb as input and impose a (temporal or quantificational) limit of some kind on the activity. They thus contribute to event structure (hence the term "superlexical"). However, they are generally denied full grammatical status because they do not constitute a perfect pf correlate to an impf verb; they can be left unpaired. For example, from the impf base Activity verb kričat', 'shout', the following verbs can be derived with a "superlexical" preverb:

(6) kričat'> za-kričat' (ingressive, 'start to shout')/po-kričat' (delimitative, 'shout for a while')/na-kričat'-sja (cumulative, 'shout a lot')/po-krik-ivat' (distributive, 'shout from time to time or at several people')/krik-nut' (semelfactive, 'give one shout').

The linguists who classify superlexicals as a functional category distinct from meaning-modifying preverbs (Smith 1991, Binnick 1991, Svenonius 2004, Ramchand 2004) essentially base their classification on the contrast between the spatial and idiosyncratic meanings provided by the latter and the more systematically temporal readings for the former. As Lakorczyk (2010) notes for Polish, however, this classificatory choice is not supported by syntactic, semantic and morphological evidence.

First, the predictability of the meanings of the superlexicals is not as systematic as has been claimed. Even one of the most common of this class of preverbs, inceptive $z a-$, is subject to idiosyncratic constraints, just like any other lexical preverb :
a. Motor za-rabota-l.
motor za-work.PF-PST.3SG
'The motor started functioning.'
b.*Ivan se-l za stol $i \quad z a-r a b o t a-l$.
Ivan sit.PF-PST.3SG at table and za-work.PF-PST.3SG
'Ivan sat down and started working.'

$\mathrm{Za}$ - is felicitous only if the inchoation or ingression occurs against the background of its absence, i.e. if the entity that initiates a process functions on a binary mode (Paillard \& Fici Giusti 1996). This explains why (7a) is felicitous, and (7b) is not.

Moreover, except for the case of distributive and delimitative po(henceforth, po-delim), all of the superlexicals give rise to telic readings. Even the case of po-delim verbs needs to be qualified for Russian, since more 
and more of them actually do occur as normal pf partners of bare impf verbs and test as telic (see section 4). Furthermore, even if some superlexicals are indeed unpaired pf verbs (e.g., the verb kričat' does not derive secondary imperfectives: *zakrikivat', *nakrikivat'sja, do not exist), many other pf superlexicals in Russian are paired with an impf verb obtained by regular secondary imperfectivization (SI):

$\begin{array}{ll}\text { za-govori-t' } & \text { / za-govar-iva-t', 'start talking' } \\ \text { za-STEM-INF } & / \text { za-STEM-2.IMPF-INF } \\ \text { za-pet' } & \text { / za-pe-va-t', 'start singing' } \\ \text { na-gulja-t'-sja } & / \text { na-gul-iva- } t \text { '-sja, 'walk to one's heart's content' } \\ \text { na-STEM-INF-REFL } & \text { / na-STEM-2.IMPF-INF-REFL } \\ \text { naest'sja } & / \text { naedat'sja, 'eat a lot' }\end{array}$

This section has shown that the three traditional categories largely overlap, both in their morphological form and their grammatical behavior. The generalization that emerges from the data presented above is that the addition of a preverb almost invariably (save for po-delim) turns an atelic predicate (an impf verb) into a telic predicate (a pf verb). I will therefore endorse the claims made by Borer (2005) and Lakorczyk (2010) that Russian preverbs are all telicity markers, with the proviso that the concept of telicity needs to be somewhat revised and extended. In particular the term must include podelim verbs, which behave more and more frequently as telic partner verbs in Russian. We will adopt a more "relaxed" notion of telicity similar to what Mehlig (2008) and Padučeva \& Pentus (2008) refer to as terminativity.

\section{Are the preverbs exponents of "pre-functional" telicity or full telicity?}

We noted immediately above that the vast majority of preverbs turn a base impf verb into a telic pf verb. This overwhelming observation should lead all authors to agree on the basic Aktionsart function of Russian aspect: it is situation aspect (SA) that is grammaticized in Russian. However, as we also saw above, superlexicals seem to be a mixed category: some of these pf verbs occur with an impf partner while others do not. For this reason, some scholars, such as Schoorlemmer (2004) and Filip $(2005,2008)$ deny a full grammatical function for the preverb.

In this section we will first discuss the influential work of Hana Filip, who assigns a pre-functional status to these preverbs. We will then argue for an alternative model, based on Borer (2005), Mehlig (2008), and Lakorczyk (2010), in which all prefixes are grammatical exponents of telicity, and the semantic notion of telicity is instantiated syntactically through a quantity range assignment to an Asp head, AspQ ( $c f$. Borer 2006:159). We will propose that 
this quantity assignment is not strict quantization, which poses the existence of an incremental relation that maps part of an individual to part of an event; rather it is terminativity.

\subsection{Preverbs as contributing a pre-functional level}

For Filip $(2000,2005,2008)$, who adopts the quantization model of Krifka, preverbs are not direct markers of telicity; telicity is, rather, epiphenomenal. Filip (2000) observes that some preverbs, particularly the $n a$ and po- superlexicals, pose a "quantization puzzle" in the sense that they do not give rise to quantized readings. Filip $(2005,2008)$ wants to preserve the insight that preverbs are lexical operators which merely add additional content (space, manner, etc.) for the calculation of telicity cum quantization based on the presence of the $M A X_{E}$ operator and a scalar structure. The $M A X_{E}$ operator is "a monadic operator, such that $\operatorname{MAX}_{E}(\Sigma) \subset \Sigma$, which maps sets of partially ordered events $\Sigma$ onto sets of maximal events $\operatorname{MAX}_{E}(\Sigma)$ " (Filip 2008: 219). The preverb merely "adds meaning components that contribute to specifying a criterion for the ordering of events in their denotation. In this way, prefixes contribute to licensing the application of $M A X_{E}$ " (Filip 2008: 244). What this implies is that preverbs express the maximality of the eventuality of a process verb, but they do not do so directly; rather, they specify the mode of execution of that maximality, which can differ according to the preverb used. Filip (2008: 245) emphasizes the fact that "the $M A X_{E}$ operator contributes to the expression of directed path structures in space and time, cardinality, measure, etc., i.e., components that have independently been uniformly represented by means of scales". The hypothesis that preverbs are "scale-inducing expressions" is supported by the fact that many impf base lexemes have several pf partners, as shown in the following pair of sentences:

(9) a. Gde moj zelënyj sviter? Ja xocu idti v nëm v magazin.

'Where's my green sweater? I want to wear it to go to the store.'

On ešče mokryj, ja ego po-stira-l. (\#vy-stira-l)

3SG still wet 1SG 3SG.ACC po-wash.PF-PST.3SG (vy-wash.PFPST.3SG)

'It is still wet, I washed it.'

b. On vy-stira-l pidžak i brjuki [...] $a \quad k$ kogda

3SG vy-wash.PF-PST.3SG jacket and pants... and when

vsë vy-sox-l-o, pro-gladi-l utjug-om. (\# po-stira-l)

all vy-dry.PF-PST-3.N, pro-iron.PF-PST.3SG iron-INS (po-wash.PFPST.3SG)

'He washed his jacket and pants [...], and when everything had dried off, ironed all of these.' (http://www.ruscorpora.ru)

Svestinskaja (1995: 172) 
In (9a), what matters in the discourse context is that the sweater is wet, rather than its having undergone a whole process leading up to it being clean; for that reason, $v y$ - would be infelicitous because it would imply a maximal degree of change on the "dirty $\rightarrow$ clean" scale. $V y$ - is felicitous in (b) for opposite reasons: the context makes it clear that what is at stake is to reach an ideal state of cleanliness for the dirty object, and po- cannot express that. Still, pf verbs with po-, such as postiral in (9), test as telic (see the discussion below).

A more serious argument in favor of Filip's model comes from the behavior of po-delim verbs, which generally test as atelic although they are pf. They stubbornly resist the $z a$-test (the in x-time frame adverbial test), and are compatible with durative adverbials:

Petja po-čita-l knig-u polčasa /*za polčasa.

Petia po-read.PF-PST.3SG book-ACC for half-an-hour / in half-an-hour

'Petia read (from) the book for half an hour/*in half an hour.'

Po- indicates that the predicates' natural (lexical) terminus is not accessible. Flier (1985) referred to these verbs as "consummations"; Kučera (1983) dubbed them "atelic events". Filip also points out that the preverb is retained in secondary imperfectivization, which in turn confirms its lexical status. One may say that the secondary impf suffix (-iva/-yva) undoes the telicity of the preverb in the pf verb. This is the path taken by Borer and Lakorczyk, to be discussed in section 5.

Filip is certainly correct to defend the hypothesis that preverbs are all lexical, that is, derivational. Russian does not possess a single meaningless prefix dedicated to marking telicity in the functional structure projected by the verb. On the other hand, one may ask: why should that be necessary? Typological studies on the grammaticalization of tense and aspect markers (e.g., Bybee, Perkins \& Pagliuca 1994) have established that whenever lexical elements change their function from lexical to grammatical, they retain some of their initial lexical content, which becomes more abstract. Such diachronic change accounts for cross-linguistic variation in the expression of notions such as perfectivity. Many scholars have noted that a Russian prefixed pf verb does not have the same grammatical function as a perfective (i.e., simple past) English verb: while the former always denote the attainment of a limit, the latter simply express closure of the event. We noted that in examples (1b) and (2) above, the prefixed pf s'ela buterbrod, 'ate a sandwich' in (1b) indicates that the event of eating the sandwich attained its completion point, it is a case of telicity cum quantization: the total consumption of the entity affected ensures that all of the event is over. Not so in (2), where the impf verb has retrospective meaning only: the sentence is uncommitted as to the actual completion of the events, and the impf verb is used. In both cases, English has to use the simple past, which shows that it is not construed in the same way. 
In conclusion, there is no contradiction in the fact that lexical material such as prepositional-like elements that grammaticalize may keep some of their lexical content (here, attainment of a completion point) while at the same time taking on a grammatical function (marking telicity). Filip's model is also partly falsified by the fact that Russian seems to be developing a default perfectivizer: po (section 4).

\subsection{What is telicity?}

The above discussion has called into question the traditional view of telicity. In the literature, it has been defined as the presence of an inherent endpoint (Vendler 1957, Dowty 1979), or in terms of event-argument homomorphism (Krifka 1998, Tenny 1992). However, as Borer (2005) notes, there are several types of telicity. The test of $i n$-x time frame adverbials probes for a very particular type of telicity, that which exists at the end of the event. Borer points out that an in-adverbial by itself does not make an atelic event telic:

(11) a. Kim ran once in two months.

b. *Kim ran in two months.

(12) a. Kim loved Robin twice last summer.

b. Kim loved Robin twice in three months.

c. ??Kim loved Robin in three months

Borer (2005: 142)

Borer proposes that in $\mathrm{x}$-time is a modifier of quantity, not an operator. It "equates the time of culmination with the actual end of the event itself" (2005: 143). For Borer, quantity readings also exist in the presence of intermediate culminations. She proposes that telic predicates, or Quantity predicates, as she calls them, are predicates that are non homogeneous.

Homogeneity is defined by the properties of being cumulative and divisive. John read books is cumulative, for example, because John read books + John read books $=$ John read books. It is also divisive because a part of 'John read books' = John read books. Predicates that are both cumulative and divisive are atelic, which is why (11b) and (12c) are rejected. Predicates that are not cumulative or not divisive are telic. For example, John read three books is not cumulative (John read 3 books + John read 3 books $=$ John read 6 books); John read 6 books is not in the denotation of the predicate John read 3 books. Likewise, John read 3 books is not divisive: a part of 'John read 3 books' $\neq$ John read 3 books. The important property is that of divisiveness. A sentence like John read many books implies divisiveness: a part of 'John read many books' $\neq$ John read many books (but John read few books). Read many books exemplifies an intermediate culmination of the type Borer claims 
is nevertheless telic, although the quantity of books remains indefinite, so that the endpoint remains vague. Similarly, the examples in (13) are telic:

(13) a. Kim ate more than enough meat.

b. We filled the room with smoke.

A predicate becomes telic at the point at which it becomes non homogeneous. In (13a), the point at which Kim ate enough meat is the endpoint. It is sufficient for there to be a quantity, which is either non divisive or non homogeneous, for a telic reading of a predicate. This definition is valid for Russian, where even perfectivizing preverbs may allow the expression of a vague quantity:

$\begin{array}{ll}\text { On } \quad \text { vy-pi-l } & \text { nemnogo vod-y. } \\ \text { 3SG vy-drink.PF-PST.3SG a-little water-GEN } \\ \text { 'He drank a little water.' }\end{array}$

Padučeva \& Pentus (2008: 200) note that the predicate in (14) is not cumulative: "if one goes on drinking, then one would, possibly, drink much water". It is not quantized either: "for some preceding interval drink some water is also true, because the predicate has the subinterval property". Rather, I propose that the event is divisive: a part of he drank a little water $\neq$ he drank a little water, but he drank very little water. The event is therefore telic because at some point it became non homogeneous. This example shows that the preverb is the exponent of terminativity, not necessarily telicity understood as strict quantization.

These examples show that the in $x$ time adverbial test is epiphenomenal: it probes for telicity-as-finality. Other tests are needed. One test that does not only test finality and duration is the cumulativity test proposed by Lakorczyk (2010: 63): it consists in coordinating two time adverbials with a given predicate. A predicate that yields either a one-event or a two-event interpretation is atelic, while a predicate that only yields a two-event interpretation is telic:

a. Kim ate meat on Monday and Tuesday.

(one or two events)

b. Kim ate 300 grams of meat on Monday and Tuesday. (two events)

c. Kim ate more than enough meat on Monday and Tuesday. (two events) Examples adapted from Lakorczyk.

(15a) is ambiguous: the sentence is felicitous if it describes either two episodes of eating meat distributed over two days, or two distinct episodes of eating meat (on each day). But for (b) and (c), only the latter interpretation obtains: (b) cannot mean that part of the 300 grams of meat gets eaten on Monday, and the other part on Tuesday; likewise, (c) does not entail that he ate enough meat on Monday and more than enough on Tuesday. Sentences (b) and (c) force us 
to understand that two distinct episodes of eating the specified quantity of meat occurred.

For Russian, this test shows that impf verbs systematically test as atelic. More importantly, it helps establish the fact that most pf procedurals (the "superlexicals") are also telic (contra Filip). For example, a $z a$-verb, which is ingressive ('start doing something') tests as telic although it focuses only the beginning point of the event and lacks duration. Filip's quantization puzzle disappears; $n a$ - verbs are in fact also telic, as well as some $p o$ - verbs:
a. On kuri-l
$v$ ponedel'nik $i$ vo vtornik. (1 or 2 events) 3SG smoke.IMPF-PST.3SG on Monday and on Tuesday 'He smoked on Monday and on Tuesday.'
b. On za-kuri-l 3SG za-smoke.PF-PST.3SG on Monday and on Tuesday 'He lit up a cigarette on Monday and on Tuesday.'
c. On po-kuri-l $v$ ponedel'nik $i$ vo vtornik. (2 events) 3SG po-smoke.PF-PST.3SG on Monday and on Tuesday 'He smoked a bit on Monday and on Tuesday.' $v$ ponedel'nik $i$ vo vtornik. (2 events)

Only (16a) can mean that the smoking episodes can extend randomly over both days. The pf verbs all imply that there were distinct episodes of smoking. Even (c), with po- delim, lexically encodes "the semantics of the end" in its meaning (Padučeva \& Pentus 2008: 209): On pokuril means 'he smoked for a while and then stopped': it gives rise to two events. In the examples above, only the impf verb, which is both cumulative and divisive, is truly atelic.

This "relaxed" notion of telicity is discussed in the Slavic literature. Padučeva \& Pentus (2008:193) observe that in English the verb form does not express terminativity, whereas in Russian it normally does, strongly so, even sometimes beyond finality, denoting a post-state:
a. Vanja pro-snu-l-sja
vsego za 5 minut.
Vanja pro-wake.up.PF-PST.3SG-REFL only in 5 minutes
'Vania woke up in only 5 minutes.'
b. $V 9$ časov Vanja uže pro-snu-l-sja.
at 9 a.m. Vanja already pro-wake.up.PF-PST.3SG-REFL
'At 9 o'clock Vania was / had already woken up.'

The pf verb in (17b) is felicitous if the post-state holds after 9. A Russian pf is often truth-conditionally equivalent to an English resultative perfect. Such post-state telicity may be enforced by the semantics of a given prefix.

It seems, therefore, that the concept of terminativity is more appropriate to describing the semantics of Russian prefixed pf verbs. As Padučeva \& Pentus (2008) and Mehlig (2008) note, all prefixed pf verbs have the "semantics of the end lexically encoded in their meaning" (ibid.). Crucially, however, terminativity need not cover the whole interval; it is not synonymous 
with quantized. The difference it allows between "absolute-terminative and relative-terminative predications" (Mehlig 2008: 258) is best observed by comparing different $\mathrm{pf}$ verbs for one single impf root. Let us consider example (9), repeated in (18).

$$
\text { Ja po-stira-l sviter } \quad v \text { ponedel'nik } i \quad \text { vo vtornik. }
$$

1SG po-wash.PF-PST.3SG sweater.ACC on Monday and on Tuesday

Although the sentence with $p o$ - is felt to be less resultative than it would be with the empty preverb $v y$-, it is nevertheless telic: (18) describes two distinct episodes of washing a sweater. It means that some washing was done on the sweater, without specification of the final state of cleanliness of the entity. As Jablonska (2004:367) says of po- in Polish: it "introduces an arbitrary Reference Time that seals off the event."

The preceding sections have shown that all preverbs, which morphologically perfectivize an impf root in Russian, can be considered as telic if the notion of telicity is revised so that finality as measured by the in-test is just one case among others. A more adequate notion is terminativity (Padučeva \& Pentus 2008, Mehlig 2008), understood as a functional operation whereby a preverb added to an atelic impf root encodes a semantics which includes the end of the event. This generalization is supported by the overwhelming empirical fact that adding a preverb in Russian automatically makes an impf root pf. This approach has the advantage of avoiding the three-fold distinction among preverbs that obscures the regularities observed, while preserving Filip's insight that prefixation retains a strong lexical origin. I concur with Lakorczyk's (2010: 83) observation that "it might be that what Filip suggests characterized an older stage in the development of Slavic aspect, but the functional role of prefixes has since been grammaticalized to a degree that can no longer be denied".

A question remains concerning po-delimitative verbs, which still test as atelic with respect to the $z a$ - test. However, as we have seen, po gives rise to several types of terminative events when accompanied by temporal adverbials. This will be illustrated in the next section.

\section{Narrowing down telicity cum terminativity: the case of po-verbs}

Many scholars have noted that the preverb po- is currently extending it use and might even become a generalized pf marker in Russian (Comrie 1976, Camus 1998, Šmelev \& Zaliznjak 1997, Dickey 2006, Guiraud-Weber 1993, Lakorczyk 2010). As Lakorczyk (2010) writes, "Slavic languages seem to be settling on a default perfectivizer - i.e., one that is most frequently applied to 
new verbs" (73). This seems to indicate that the grammaticalisation of SA is becoming firmly entrenched in Russian.

Po- is the most polysemous prefix of all; it usually has the following senses:

a. inchoation:

$$
\begin{aligned}
& \text { po-exa-t', po-ljubi-t' } \\
& \text { po-go.PF-INF po-love.PF-INF } \\
& \text { 'set off', 'fall in love'. }
\end{aligned}
$$

b. distributive-cumulative:

$$
\begin{array}{lll}
\text { po-ubi-va-l } & \text { by } & v s e x ! \\
\text { po-kill.PF-DISTR-PST.3SG } & \text { COND } & \text { all.ACC.PL }
\end{array}
$$

'I'd kill them all one after the other!'

c. delimitative:

$$
\begin{array}{llll}
\text { po-kolo-l } & \text { drova } & \text { s polčasa } i & \text { ušël, } \\
\text { po-chop.PF-PST.3SG } & \text { wood.ACC.PL half-an-hour and left }
\end{array}
$$$$
\text { 'He chopped at some wood for a half-hour and left.' }
$$

d. attenuative/limitative:

$$
\begin{aligned}
& \text { kofe po-osty-l } \\
& \text { coffee.NOM po-cool.PF-PST.3SG } \\
& \text { 'The coffee has cooled down a bit.' }
\end{aligned}
$$

e. resultative:

$$
\begin{array}{lll}
\text { po-stroi-t } t \quad d o m, & \text { po-čini-t' } & \text { časy } \\
\text { po-build.PF-INF house.ACC } & \text { po-fix.PF-INF } & \text { watch.ACC } \\
\text { 'build a house', 'fix a watch'. } &
\end{array}
$$

f. perfectivizing:

po-duma-t', po-rabota-t', po-veri-t', po-čuvstvova-t', po-think.PF-INF, po-work.PF-INF, po-believe.PF-INF, po-feel.PF-INF 'think', 'work', 'believe', 'feel'.

The use that poses a problem for quantized accounts of telicity is delimitative po- (in c). It denotes limited duration for an atelic event and thus tests as atelic in the $z a$ - test, as we have seen. Recall, however, that the $z a$ - test probes for one case of telicity, the one that measures the attainment of the telos or inherent boundary. The $z a$ - test does not apply here, because the event has no telos: poindicates limited duration and thus has the effect of stripping the predicate's denotation of a telos.

Given the overwhelming empirical generalization that all preverbs in Russian make an impf root pf, we want to preserve the insight that all preverbs impose a boundary on the event. At this point we will introduce some facts which modify the assertion generally made about po-delim verbs. 


\subsection{What po-delim verbs are not}

Some of the claims made in the literature about the po-delim pf verbs are not verified.

\subsubsection{Extension of functional scope}

In Russian, "delimitative" po-verbs display a tendency to develop into real perfective partner verbs" (Šmelev \& Zaliznjak 1997: 112). They are clearly extending their functional scope, and are not systematically atelic; some even test as telic with the $z a$ - frame adverbial test (Mehlig 1985):
a. My po-krasi-l-i
zabor
časa $d v a$ se-l-i
1PL po-paint.PF-PST-3PL fence.ACC hours two and sit.PF-PST-3PL zavtrakat'
for-breakfast
'We painted (on) the fence for two hours and sat down to have breakfast.'
b. My po-krasi-l-i zabor za dva časa.
1PL po-paint.PF-PST-3PL fence.ACC in two hours
'We painted the fence in two hours.'

There's not a great distance between the delimitative in (20a), 'painted on the fence' to a real resultative in (20b), 'painted the fence'. Many verbs show this semantic variability.

\subsection{2. po-delim verbs do not necessarily indicate short duration}

Many authors have noted that in fact they express indefinite duration (Isačenko 1960, Flier 1985, Dickey 2006). The short duration reading is usually inferred; it is easy to override the inference, as in the following example:

\footnotetext{
"Skaž-ite, [...] vot ja id-u po ulice, say-IMP.2PL here 1SG walk.IMPF-PRS.1SG down street

In (21), we infer that the person smoked the whole cigar, because now he wants to throw away the stub and cannot find a trash can; the duration of the event would be the same if instead the natural perfective was used (vykuril sigaretu). This minimal pair shows that what is at stake with po- is not lexical telicity (presence of the event's inherent culmination), but rather terminativity: po- indicates that an entire episode of smoking took place, regardless of the 
final state of the (often unexpressed) affected object or of the duration of the episode.

\subsubsection{Lexical restrictions}

Although the number of impf roots that derive a po-pf verb is very large, they are subject to lexical restrictions having to do with the presence or absence of scales in the semantics of the base verb. From that perspective, po- is no different from the other preverbs that are also subject to constraints. This suggests that there is no reason to exclude po-from the class of purely perfectivizing or meaning-modifying preverbs. Change of state verbs illustrate a restriction of the use of vy-vs po-perfectives (Svetsinskaja 1995: 170).

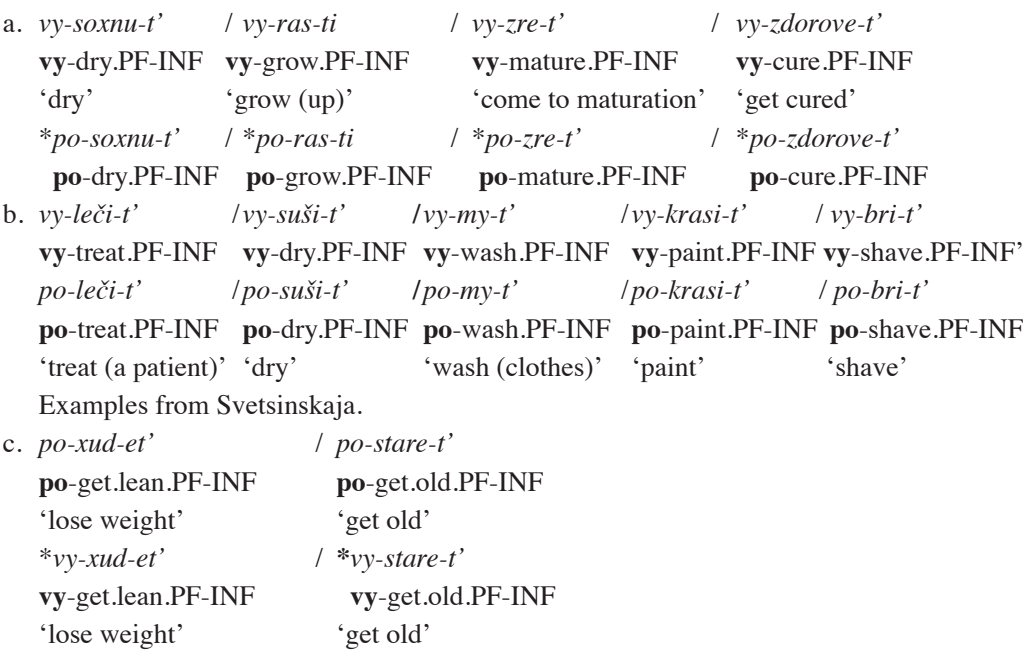

The intransitive change of state verbs in (22a) do not accept po-verbs, because they denote an absolute change of state; $v y$ - is a good candidate for these verbs precisely because it indicates that the undergoer (patient, theme) ends up in the state that corresponds to an ideal (abstract) model of what the bare root means: 'completely dry, grown, ripe, healthy'. Po- is possible, however, with the transitive change-of-state verbs in (22b): these roots denote a non-necessary final state; $p o$ - is appropriate because it indicates a less than complete degree on the scale of treatment/drying/painting/washing, etc. Moreover, the degree achievements in $(22 \mathrm{c})$, which do not encode a final point, accept only a po- pf partner. 


\subsection{What po-delim verbs are}

Our discussion leads to the conclusion that $p o$ - delim verbs are a special case of terminative (telic) verbs. The type of bound they impose on the event is not an inherent one (the bound that the natural telos of the predicate entails), but an external type of bound. As has often been noted, $p o$ - imposes temporal definiteness. For Flier(1985), a po-verb denotes relative change: it takes as input a homogeneous event (an atelic activity) and delimits it on the temporal axis. According to Mehlig (2006), the role of po-verbs in aterminatives is to provide "external bounding" by focusing on a certain quantity of the homogeneous temporal continuum, that is, a limited period of its duration, so that the output is "arbitrary boundedness" of the event. For Sémon (1986), as well, contrary to other prefixed pf verbs, $p o$ - verbs do not describe the endpoint of action, but the amount of process that the speaker judges "congruent" (sufficient) in a given stretch of discourse. Finally, for Dickey (2006), po- verbs identify a situation as unique in a sequence or a set of events. It is the reason why such verbs pass the temporal adverbial test of telicity proposed above.

Although full discussion of $p o$-verbs would take us too far afield, there is a growing consensus that the language is changing, with po-delim verbs being often indistinguishable from normal po-pf verbs. In many cases, they perform the same function as a pure perfectivizer by placing the events in a narrative succession of non-overlapping situations; then they co-occur naturally with purely perfectivizing prefixed verbs:

$$
\begin{aligned}
& \text { Eto ved'tuda-sjuda-obratno, po-e-l, po-čita-l } \\
& \text { this is here-there-back, po-eat.PF-PST.3SG, po-read.PF-PST.3SG } \\
& i \quad u \text {-pa-l lico-m v podušk- } u \text {. } \\
& \text { and u-fall.down.PF-PST.3SG face-INS in pillow-ACC } \\
& \text { 'He was like, moving about here and there all the time, he ate first, read a bit, } \\
& \text { and fell crashing head first into the pillow.' } \\
& \text { Russian National Corpus }
\end{aligned}
$$

Dickey (2006: 16) notes the important grammatical function of the preverb po- in the aspectual system of Russian; it allows "the extension of the aspect opposition to atelic activity predicates ... [it] allow[s] activity predicates to be sequenced in time on a par with telic predicates". Without po-, the aspect opposition would "be restricted to accomplishment and achievement predicates", much as in Czech and Bulgarian, where aspect is more lexical ( $c f$. Lakorczyk 2010). In sentence (23), the sequencing of the events in time invalidates the use of bare impf verbs; the pure perfectives ( $\boldsymbol{s}^{\prime} \boldsymbol{e l}$, pročital) are not possible either because they would require the presence of a completely affected argument, which is not the case.po- thus fills an important grammatical role, akin to that played by lexical telicity with empty preverbs: the po-verb indicates "contingent" telicity, which we express by the general term of 
terminativity. For accomplishment and achievement predicates, terminativity translates into lexical telicity (attainment of the final point), whereas for activities and some state predicates, terminativity means contingent telicity, i.e. what Dickey calls the expression of "tangential consequences" for the event, as opposed to its natural consequence as expressed by the pure preverb in conjunction with a bare impf root.

As it is sometimes very difficult to draw the line between a po-delim and a normal po-pf partner verb, a careful corpus search would be necessary. In the following example, drawn from Dickey (2006), the po-delim verb takes an accusative object, i.e. a "single referential object", a construal which is normally possible only with pure perfectivizers.

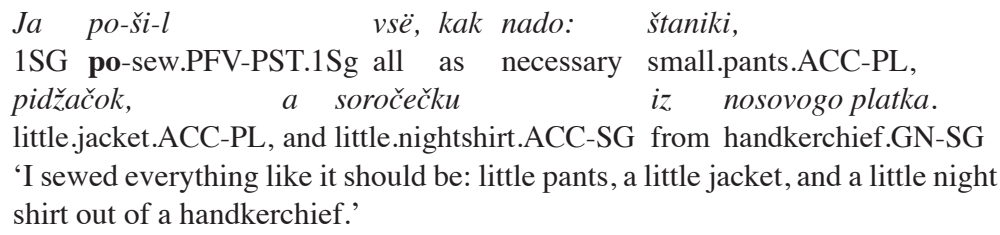

These facts lead Dickey to define an aspectual pair as "not a function of a dictionary, but a condition of mutual activation linking two verbs of opposing aspects at a given stage in the development of a discourse" (Dickey 2006: 33).

In this section I have examined the puzzle posed by po-delim verbs, which often test as atelic in the $z a$ - frame adverbial test, yet yield positive results in other telicity tests, such as the time adverbial test. The former test probes for mereological telicity, that which covers the whole interval, including the beginning point and focusing on the endpoint: this explains why a sentence like on počital knigu čas, 'he po-read the book for an hour', is possible. Popicks an arbitrary temporal interval in the event and simply seals it off, which a specialized preverb (pro- in pročital knigu, 'read the book through') does not do, as it fixes the natural bound for the event, by definition. The latter test (the time-adverbial test) probes for a relaxed notion of telicity, that which I call terminativity, which simply measures the end of an event: on that count, on počital knigu means 'he read the book for a while and then he stopped reading.' Following a number of authors, I also noted that the language is changing and that $p o$-delim perfectives often behave as normal perfective telic partners of impf bare verbs, except for the attainment of the inherent culmination. I therefore proposed a more general definition of telicity for Russian, which I call terminativity, similar to the concept developed by Padučeva \& Pentus (2008), and Mehlig (2008). The advantage of this revised conception of telicity is that it provides a single function for all the preverbs, avoiding postulating a special case for $p o$-delimitatives, and $n a$-cumulatives. It gives more flesh to 
the concept of perfectivity which, as will be demonstrated below, need not be ascribed to the expression of viewpoint aspect.

This will be the topic of the last section: if po-delim perfectives induce terminativity, wouldn't it be better to assume that alongside the telicizing role of preverbs, one must assign them another function, that of marking viewpoint aspect? And what is left of the preverb when the operation of secondary imperfectivization (SI) occurs? I turn to these topics in the concluding section.

\section{Are preverbs telicizers or perfectivizers?}

According to Smith (1991), viewpoint aspect (outer aspect) establishes a relation between the assertion time (AT) and the event time (ET). If ET is included in AT, there is an external view of the situation seen as a whole, whatever its actual length; the situation is temporally bounded, producing the perfective viewpoint (PF). If, on the other hand, AT is included in ET, there is an internal view of the situation; the situation is temporally unbounded, deriving the imperfective viewpoint (ImpV). VA aspect then composes with SA to yield different aspectual construals of situations: for atelic situations (Activities and States), application of the PF yields events that merely terminate:

(25) John read books $\rightarrow$ \#John finished reading books; John stopped reading books.

For Accomplishments and Achievements, application of the same operator gives events that culminate:

(26) John read the book $\rightarrow$ John finished reading the book

Lakorczyk (2010) uses a time adverbial test to avoid confusing atelicity and imperfectivity; only events with the PF "can have an inclusive reading with respect to a time interval, i.e. they do not need to fill the whole time interval" (55), while events with ImpV can only have a durative reading:
Between 2 and 3, John read a book.
(durative or inclusive)
Between 2 and 3, John was reading a book.
(only durative)

In Russian, as already noted in the introduction, an impf verb normally produces an unbounded (view from within) interpretation (Klein 1995):

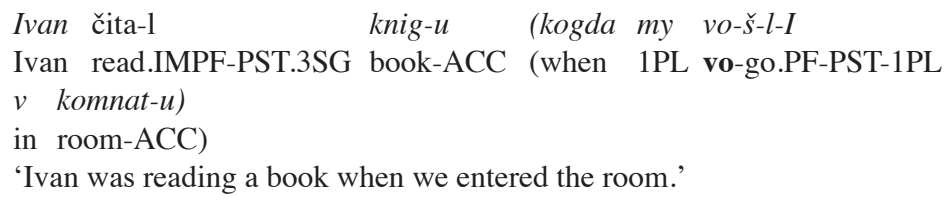

Crucially, however it does not necessarily derive an ImpV reading, even in the presence of a temporal adverbial: 


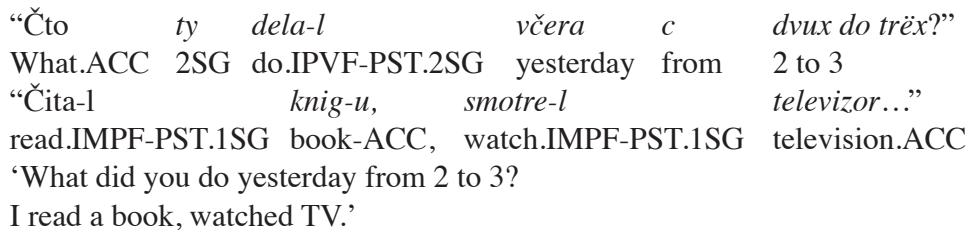

The normal way of asking about one's past (and bounded) activities is by using the impf verb, as in (29). This shows that the impf verb does not necessarily encode the ImpV. The verbs in (29) are most naturally translated as simple pasts in English, indicating that both bounds of the event are included in the assertion time. However, a pf verb always denotes a closed interpretation, i.e. it invariably produces the PF. A useful test is to add the adverb uže, 'already', to an impf or a pf verb, as in (30a-c).
a. 'Vot, ot-stuč-is'
sejčas, Raisa Vasil'evna, prikaz."
well, ot-type.PF.
On uže side-l
$\mathrm{V}$.
order.ACC
3SG already sit.IMPF-PST.3SG and write.IMPF-PST.3SG
'Well now, you'll have to type the order, Raisa Vasilievna. He was already sitting and writing.'
b. Kažetsja, ja uže pisal, čto on it-seems $1 \mathrm{SG}$ already write.IMPF-PST.3SG that 3SG
ne otliča-l-sja osoboj ljubeznost'ju.
NEG distinguish.IMPF-PST-REFL.3SG special.INS affability.INS
'It seems I've already written that he did not appear as particularly affable.'
c. Nu, a ja tol'ko mogu povtori-t' to, čto
well, and 1 SG only can.PRS repeat.PF-INF that which
uže na-pisa-l.
already na-write.PF-PST.1SG
'Well, I can only repeat what I've already written.'

In (30a-b), the combination of uže and the impf verb pisal is ambiguous between an ImpV (was already writing) and a PF (have already written). However, (30c), with the prefixed pf verb napisal, has only a completive sense (have already written); it illustrates the PF.

Clearly, it would be incorrect to assign the PF aspect function to the preverb (e.g., na- in napisal), since the impf verb expresses the PF just as well. I thus arrive at the same conclusion as Lakorczyk (2010): "Viewpoint aspect in languages such as Polish and Russian is marked by zero morphology.”(90). VA is expressed in Russian by means of correlations or compositional restrictions such as the following: 


\begin{tabular}{|c|c|c|c|c|}
\hline Morphology of verb & & Situation type & & Viewpoint type \\
\hline Base impf verb & $\rightarrow$ & atelic & $\rightarrow$ & $\begin{array}{l}\text { perfective or } \\
\text { imperfective viewpoint. }\end{array}$ \\
\hline Preverb + base impf verb & $\rightarrow$ & telic & $\rightarrow$ & perfective viewpoint. \\
\hline
\end{tabular}

In Russian, a base impf verb denotes an atelic eventuality which receives either a PF or an ImpV reading. The addition of a preverb to the base impf verb makes it terminative/telic, deriving a PF reading. We conclude that the preverb has a telicizing/terminative function. Therefore, it is SA that is grammaticized in Russian, not VA.

I will conclude this study with two arguments, which also apply to Polish (Lakorczyk 2010), to show that preverbs do not have a viewpoint aspect function (i.e., are not perfectivizers):

1. preverbs are found in forms that do not have to have PF interpretation, namely, secondary imperfective (SI) forms;

2. preverbs do not have a VA interpretation at all in non-finite forms (nominals), where no temporality can be retrieved.

\subsection{Secondary imperfectivization (SI) and preverbs}

SI is a regular morphological process whereby a prefixed pf verb derives its impf partner via $a /$-iva/-yva suffixation (or exceptionally, suppletion). Examples (3) and (4) are repeated as (31), with the SI formations added:

$$
\text { base impf verb: bit', 'beat, hit'. }
$$

a. prefixed perfectives: $\quad u$-bit' (čeloveka), 'kill (a man)'; raz-bit' (stakan), 'break (a glass)'; po-bit' (sobaku), 'beat a dog'; pro-bit' (dorogu), 'open up (road)'; za-bit' (trevogu), 'raise (the alarm)'.

b. secondary imperfectives: u-bi-va-t; raz-bi-vat'; po-bi-vat'; pro-bi-vat'... u-STEM-2.IMPF-INF

Filip (2005, 2008) used SI as an argument for denying a telicizing function to the preverb, since the preverb remains in SI formations. The question is to determine the grammatical function of SI. The regular and inflectional-like nature of this process has led many authors (e.g., Zucchi 1999) to analyse it as a progressive operator, taking as input a culminated event (e.g., ubit' 'kill') and yielding an imperfective event (ubivat'), much like the progressive in English. The problem for that account is that a SI verb behaves exactly like a bare impf verb: it can denote either a progressive (32a) or a bounded event, as in (32b): 
a. Kogda ja pri-së-l, oni za-kaz-yva-l-i

When 1SG pri-go.PF-PST.1Sgarrived 3PL za-order-2.IPF-PST-3PL

bljuda.

dishes.ACC

'When I arrived, they were ordering the food.'

b. -Kak nazyvaetsja eta ryba? - sprosil Kostia u Vari how call.3SG-REF this fish ask.PFV-PST-3SG Kostia from Varja -Vy ved' za-kaz-yva-l-i karp-a, -otvetila Varja, 2PL well za-order.2.IPFV-PST-3PL carp.ACC answer.PFV-PST-3SG Varja -on i est', po-vidimomu.

It PART be apparently

"What's the name of that fish?" - Kosti asked Varia.

"Well, you ordered a carp, didn't you? - answered Varia. "That's what it is, obviously."

(32b) illustrates a very frequent use of impf verbs in conversations, in which the addressee is reminded by the speaker of a fact that she should have been aware of; (Forsyth, 1970) calls it the "statement of fact" convention; the SI suffix $-y v a$ is not a marker of ImpV. Rather it behaves like any other bare imperfective and can be temporally unbounded as well as bounded. I thus concur with Lakorczyk (2010) in analyzing the SI suffix as an atelicizer, which simply undoes the telicity of the preverb, but crucially not as a progressive (ImpV) operator.

Further confirmation of this function comes from the behavior of nominals.

\subsection{Nominals}

Deverbal nominals in Russian take an -'e/-'ё/-ie suffix, added to a verb stem regardless of its aspect and voice.
a. voz-vrat-it'-sja > voz-vrašče-nie
voz-turn.PF-INF-REFL voz-turn-NMLZ
'to come back' $>$ 'return'
b. stroi-t'
'to build'
build.IMPF-INF
$>$ stroe-nie
$>$ build-NMLZ
c. na-pisa-t'
na-write.PF-INF
'to write'
d. rva-t'
tear.IMPF-INF
'to tear' 'construction'
$>$ na-pisa-nie
$>$ na-write-NMLZ
'writing, inscription'
$>\quad r v a-n ’ \ddot{e}$
$>$ tear-NMLZ
'torn clothes'

The verb is pf and reflexive (with the suffix -sja) in (a), bare impf in (b), prefixed pf in (c), and bare impf in (d). Semantically, the deverbal nominal 
denotes a result in (a), a process in (c), a process or a result in (b), and more idiosyncratically, an entity in (d). The fact that an eventive nominal formed from an impf (33b,d) as well as a pf (a,c) verb, is compatible with an imperfective construal, e.g. with the preposition pri, 'during', as in (34a-d), suggests that the eventive nominal simply lacks VA:
a. pri po-stro-eni- $i$
model-i
pri po-build-NMLZ-DAT model-GEN
'during the construction of the model'
b. pri na-pisa-ni-i
roman- $a$
pri na-write-NMLZ-DAT novel-GEN
'during the writing of the novel'
c. Eto očen' meša-et mne pri pisa-ni-i
it.N much disturb-PRS.3SG me.DAT pri write-NMLZ-DAT
'It disturbs me a lot during my writing.'
d. pri pisa-ni-i nov-yx glav on
pri write-NMLZ-DAT new-GEN.PL chapter.GEN.PL 3SG
ponja-l...,
understand.PF-PST.3SG
'During the writing of new chapters he understood...'

The choice between the pf or the impf base for deriving the nominal seems to depend on the absence $v s$ presence of an object, and/or the nature of the direct object (single referential object $v s$ generalized object). (34a) and (b) have a singular delimited (referential) object which requires a perfective base; (34c) and (d) create contexts which require the use of the impf base: there is no object in (c) - the activity of writing is focussed - while (d) has a plural object. Such facts suggest that it is not VA but SA that dictates the choice of the base form of a derived nominal, including presence/absence of a bound and focus on the process or the result.

This observation is confirmed by the interpretation of the nominalizations of SI verbs: these always denote atelic processes, never results, and do not introduce any temporal effects which would suggest a progressive VA interpretation:
a. za-pis-yva-nie
zvuk-ov
na plastink-e
za-write-2.IMPF-NMLZ sound-GEN.PL on record.LOC.SG
'the registration of sounds on a record'
b. po-kaz-yva-nie kartin-ok
po-show-2.IMPF-NMLZ painting-GEN.PL
'the showing/display of paintings'

The data shown here indicate that SA alone is grammaticalized in Russian, and that the contribution of the preverb is limited to its Aktionsart function of marking telicity/terminativity. The role of SI is to undo the telicity inherent in the preverb + bare impf base. 


\section{Conclusion}

This paper has presented the complex data of verbal prefixation in Russian, and has assessed its role in the marking of situation and viewpoint aspect. It has defended the view that telicity is a robust functional feature which finds its grammatical exponent in the pure perfective preverbs. This view, defended by Borer (2005), and Lakorczyk (2010) for Polish, is based on the generalization that a preverb invariably makes an impf atelic root telic. Concurrent models were examined, e.g. that of Filip $(2005,2008)$, which seeks to retain the strong lexical (derivational) nature of the preverbs and deprives the preverb of a generalized telicizing function, preserving the classification into three types of preverbs. Instead, it was shown that there was a large overlap in the properties of the purely perfectivizing, the meaning-modifying and the superlexical preverbs: all yield telic readings, with the possible exception of po-delim pf verbs. It was further noted that even if the purely perfectivizing preverbs have grammaticalized to a large extent, they still retain part of their lexical substance and have not been replaced by a single empty prefix to do the job, confirming typological studies on the grammaticization of tense and aspect markers (Bybee, Perkins \& Pagliuca 1994). It was also observed that both the superlexicals and the purely perfectivizing are subject to lexical constraints, just like the meaning-modifying preverbs.

In turn, the behavior of the superlexicals forced us to relax the exclusive definition of telicity found in the literature, viz. telicity as quantization. It was suggested that non-homogeneity or non-divisiveness alone can support a telic reading. Following the model of Borer (2005), I endeavored to show that final telicity is just one case of telicity, with many other preverbs in Russian (na-, po-) encoding either non divisiveness or "post-state" telicity. Then, the behavior of po-delim verbs, which are currently extending their functional use in Russian, provided a further argument in favor of the relaxed view of telicity advocated above: even if po-delim verbs do not encode lexical telicity (i.e., presence of an inherent culmination in the verb's denotation), they mark terminativity, i.e. they encode a semantics of the end, which I called terminativity, following Padučeva \& Pentus (2008), and Mehlig (2008).

Finally, the data about po-delim verbs raised the question of the expression of viewpoint aspect: it was shown that both bare impf and secondary impf verbs, can give rise to an imperfective as well as a perfective viewpoint interpretation; however, pf verbs only yield a perfective viewpoint interpretation. With the observation that eventive nominals, derived from a pf or an impf verb, are deprived of any viewpoint construal, we were comforted in the conclusion already arrived at by Kiss (2006) for Hungarian, that it is situation aspect, not viewpoint aspect, that is grammaticized in Russian. The latter is merely inferred compositionally. 


\section{REFERENCES}

AviLova, Natalia (1976). Vid glagola i semantika glagol'nogo slova [Verb aspect and the semantics of the verbal word]. Moskva:Nauka.

Binnick, Robert (1991). Time and the Verb: A Guide to Tense and Aspect. New York and Oxford: Oxford University Press.

BONDARKO, Aleksandr (1971). Grammatičeskaja kategorija i kontekst ["Grammatical category and context"], Leningrad: Nauka.

Borer, Hagit (2005). The Normal Course of Events. Oxford, New York, Oxford University Press.

BRECHT, Richard D. (1985). The form and function of aspect in Russian. In Flier, M. S. \& Brecht, R. D. (eds.), Issues in Russian Morphosyntax: 9-33. Columbus, Ohio: Slavica Publishers.

Bybee, Joan; Perkins, Revere; Pagliuca, William (1994). The Evolution of Grammar: Tense, Aspect and Modality in the Languages of the World. Chicago: The University of Chicago Press.

CAmus, Rémi (1998). Quelques considérations sur le préverbe po- en russe contemporain. Revue d'Études Slaves 70/1: 101-112.

ComrIE, Bernard (1976). Aspect. Cambridge: Cambridge University Press.

DiCKEY, Stephen M. (2006). Aspectual pairs, goal orientation and po-delimitatives in Russian. Glossos Issue 7: 1-37.

Dowty, David R. (1979). Word Meaning and Montague Grammar. Dordrecht: Reidel.

FILIP, Hana (2000). The quantisation puzzle. In Pustejovsky, J. \& Tenny, C. (eds.), Events as Grammatical Objects, from the Combined Perspectives of Lexical Semantics, Logical Semantics and Syntax: 3-60. Stanford: CSLI Publications.

FILIP, Hana (2005). On accumulating and having it all. Perfectivity, prefixes and bare arguments. In Verkuyl, H.; de Swart, H. \& van Hout, A. (eds.), Perspectives on Aspect: 125-148. Dordrecht: Springer.

FILIP, Hana (2008). Events and maximalization: the case of telicity and perfectivity. In Rothstein (2008): 217-253.

FLIER, Michael S. (1985). The scope of prefixal delimitation in Russian. In Flier, M. S. \& Timberlake, A. (eds.), The Scope of Slavic Aspect, UCLA Slavic Studies, vol. 12: 41-58. Columbus, Ohio: Slavica Publications.

Forsyth, James (1970). A Grammar of Aspect. Usage and Meaning in the Russian Verb. Cambridge: Cambridge University Press.

GuIRAUd-WebER, Marguerite (1993). Le préverbe po- en russe moderne. La Revue Russe 5: 57-68.

IsAČENKO, Aleksandr V. (1960). Grammatičeskij stroi russkogo jazyka v sopostavlenii s slovackim : morfologija, čast' 2 ["The structure of the Russian language compared with Slovak, part. 2"], Bratislava.

JABLONSKA, Patrycja (2004). When the prefixes meet the suffixes. In Svenonius (2004): 363401.

JANDA, Laura (2007). Aspectual clusters of Russian verbs. Studies in Language 31/3: 607648. John Benjamins.

Kiss, Katalina (2006). The Function and Syntax of the Verbal Particle. In Kiss, K. (ed.), Event Structure and the Left Periphery. Studies on Hungarian: 17-56. The Netherlands: Springer. 
KLEIN, Wolfgang. (1995). A time-relational analysis of Russian aspect. Language 71/4: 669695.

KRIFKA, Manfred (1998). The origins of telicity. In Rothstein, S. (ed.), Events and Grammar: 197-236. Dordrecht: Kluwer Academic Publishers.

KuČERA, Henry (1983). A semantic model of verbal aspect. In Flier, M. S. (ed.), American Contributions to the Ninth International Congress of Slavists. Kiev, September 1983, vol. 1: 171-184. Columbus, Ohio.

LAKORCZYK, Agnieszka (2010). Decomposing Slavic Aspect: the Role of Aspectual Morphology in Polish and other Slavic Languages. PhD dissertation, Faculty of the USC Graduate School, University of Southern California.

MASLOV, Ju.(1948). Vid i leksičeskoe značenie glagola v sovremennom russkom literaturnom jazyke ["Aspect and the lexical meaning of verbs in Russian contemporary literary language"]. Izvestija Akademii nauk SSSR, Otdelenie literatury i jazyka 7/4: 303316.

MehLIG, Hans Robert (1985). Aspektsemantik, Satzsemantik und Negation. In W. Lehfeldt (ed.), Slavistische Linguistik 1984: 174-210. München: Verlag Otto Sagner.

MeHLIG, Hans Robert (2006). Glagol'nyj vid i vtoričnaja gomogenizacija oboznačaemoj situacii posredstvom kvantifikacii: $\mathrm{k}$ upotrebleniju delimitativnogo sposoba dejstvija v russkom jazyke ["Verbal aspect and the secondary homogeneization of a described situation by means of quantification: use of the delimitative Aktionsart in Russian"]. In Semantika i struktura slavjanskogo vida [The Semantics and Structure of Russian Aspect], Slavolinguistica 5, 235-276.

MeHLIG, Hans Robert (2008). Aspect and bounded quantity complements in Russian. In Rothstein (2008) : 257-291.

PAdučEva, Elena; Pentus, Mati (2008). Formal and informal semantics of telicity. In Rothstein (2008): 191-215.

PAILlARD, Denis ; FicI GiUsti, Francesca (1996). L'inchoation entre préverbes et auxiliaires. In Le Langage et l'Homme XXXIII/1: 79-94. Louvain.

RAMCHAND, Gillian C. (2004). Time and the event: The semantics of Russian prefixes. In Svenonius (2004): 323-361.

Rothstein, Susan (ed.) (2008). Theoretical and Crosslinguistic Approaches to the Semantics of Aspect. Amsterdam: Benjamins.

SÉmon, Jean-Paul (1986). Postojat' ou la perfectivité de congruence : définition et valeurs textuelles. Revue des Études Slaves 58/4 : 609-635.

SÉmon, Jean-Paul (2008). Des imperfectifs prétérits étranges. In Roudet, R. \& Zaremba, C. (eds.) Questions de linguistique slave, études offertes à M. Guiraud-Weber: 305315 .

ŠMELEV, Aleksej; ZALIZNJAK, Anna (1997). Leksii po russkoj aspektologii ("Lectures on Russian aspectology"), Slavistische Beiträge 353. Munich: Verlag Otto Sagner.

SMIth, Carlota (1991). The Parameter of Aspect. The Netherlands: Kluwer Academic Publishers.

Svenonius, Peter (ed.) (2004). Special Issue on Slavic Prefixes. Nordlyd 32/2: 177-204. Troms $\emptyset$, CASTL. Available on: http://www.ub.uit.no/munin/nordlyd/

Svetsinskaja, I. (1995). Le Préverbe vy-en russe contemporain : étude sémantique et syntaxique. Thèse de doctorat, INALCO.

TENnY, Carol (1994). Aspectual Roles and the Syntax-Semantics Interface. Dordrecht/ Boston: Kluwer Academic Publishers. 
Tixonov, Alexander (1962). K voprosu o čistovidovyx pristavkax v sovremennom russkom jazyke [Empty prefixes in modern Russian]. Travaux de l'université d'État de Samarkand 118: 31-57.

TOURNADRE, Nicolas (2004). Typologie des aspects verbaux et intégration à une théorie du TAM. Bulletin de la Société Linguistique de Paris XCIV/ 1: 7-68.

VENDLER, Zeno (1957). Verbs and times. In Linguistics in Philosophy (1967): 97-121. Ithaca, New York: Cornell University Press.

Vinogradov, Viktor V. (1972). Russkij jazyk [The Russian Language], $2^{\text {nd }}$ ed. Moscow: Vysšaja škola.

ZuCCHI, Sandro (1999). Incomplete events, intensionality and imperfective aspect. Natural Language Semantics 7: 179-215.

\section{RÉSUMÉ}

L'article poursuit deux objectifs: présenter les données complexes de la préfixation verbale (préverbation) en russe, et interroger la validité de la distinction entre aspect lexical (Situation Aspect) et aspect grammatical (Viewpoint Aspect) établie par Smith (1991), et en particulier la thèse selon laquelle tous les préverbes sont des marqueurs de télicité (Borer 2005). En premier lieu, des arguments sont avancés pour montrer que tous les verbes préverbés sont systématiquement perfectifs (pf); tous sont sujets à des restrictions lexicales. Une conclusion préliminaire est que tous les préverbes marquent la télicité, contre Filip $(2005,2008)$ pour qui le préverbe est préfonctionnel (lexical). Cela pose la question de la nature exacte de la télicité. Dans la littérature (Dowty 1979, Krifka 1998), la télicité est testée au moyen des adverbiaux de type «en x temps». Une version plus lâche de la télicité est proposée, à la suite de Borer (2005) et Lakorczyk (2010): il suffit qu'un événement soit non divisible ou non homogène pour qu'il soit télique. Ce concept est proche de celui de «terminativité» défendu par Paducheva \& Pentus (2008) : la fonction du préverbe est de clôre l'événement. Ceci permet de rendre compte du comportement des verbes munis du préverbe délimitatif po-. Les données montrent que ces hypothèses ne sont pas exactes: les verbes en po- connaissent une extension fonctionnelle de leur emploi en russe contemporain et, de plus en plus, sont des partenaires pf normaux du verbe impf correspondant; ils n'indiquent pas nécessairement une durée courte, et sont également soumis à des restrictions lexicales (Dickey 2006). Enfin, le rôle du préverbe vis-à-vis de l'aspect grammatical est évalué. En conclusion, c'est l'aspect lexical (Situation Aspect) qui est grammaticalisé en russe au moyen des préverbes, et non l'aspect grammatical (Viewpoint Aspect), dérivé au moyen de simples corrélations.

\section{MotS-CLÉS}

Russe, aspect grammatical, aspect lexical, telicité, perfectivité. 